\title{
PENGARUH WATER AWARENESS TERHADAP KINERJA PERUSAHAAN
}

\author{
Agustine Dwianika* \\ (Universitas Pembangunan Jaya)
}

\section{ARTICLE INFO}

Keywords:

Water Awareness, Company Performance, Manufacturing Companies

\section{ABSTRACT}

Cost reduction can be done with the efficiency of water governance. The good environmental awareness's driver is very important in governance practices. The phenomenon of water scarcity especially for industry can hamper business sustainability. Especially related to the firm's performance on an ongoing basis. This study aims to provide empirical support for new measurement models in an effort to improve the sustainability of firm's performance. And taking into account the awareness of water management and the work area environment. 100 respondents were taken with a purposive sampling method that represents 20 manufacturing companies. This study describes a water awareness analysis of firm's performance. The results show that the water awareness supporting to the firm's performance continously improvement.

Especially, this models possible to implement for manufacturing companies in Indonesia.

\section{ABSTRAK}

Pengurangan biaya dapat dilakukan dengan efisiensi tata kelola air. Pendorong kesadaran lingkungan yang baik sangat penting dalam praktik tata kelola. Fenomena kelangkaan air terutama untuk industri dapat menghambat keberlangsungan bisnis. Terutama terkait dengan kinerja perusahaan secara berkelanjutan. Studi ini bertujuan untuk memberikan dukungan empiris untuk model pengukuran baru dalam upaya untuk meningkatkan keberlanjutan kinerja perusahaan dan dengan mempertimbangkan kesadaran pengelolaan air dan lingkungan area kerja. 100 responden diambil dengan metode purposive sampling yang mewakili 20 perusahaan manufaktur. Studi ini menjelaskan analisis kesadaran air terhadap kinerja perusahaan. Hasilnya menunjukkan bahwa kesadaran air yang mendukung kinerja perusahaan terus meningkat.

Terutama, model ini mungkin diterapkan untuk perusahaan manufaktur di Indonesia

\section{How to Cite:}

Agustine Dwianika. (2020). Pengaruh Water Awareness Terhadap Kinerja Perusahaan. Jurnal Ilmiah Wahana Akuntansi, 15(1), 15-24 https://doi.org/10.21009/wahanaakuntansi/15.1.02 


\section{PENDAHULUAN}

Baru-baru ini, krisis air banyak dibahas dalam berbagai forum kesadaran lingkungan. Indonesia sendiri diprediksi adanya krisis air. Berdasarkan data dari Badan Regulasi Air Minum di Jakarta, dari 2010-2025 akan terjadi krisis air sebanyak 35,786 liter per detik (Kompasiana, 2018). Bahkan World Resources Institute (2017) juga memberikan pernyataan serupa bahwa Indonesia menjadi salah satu negara dengan tingkat kekurangan air dengan tekanan tinggi (water stress) di tahun 2040.

Salah satu penyebabnya adalah kurangnya kesadaran terhadap keberlangsungan lingkungan sekitar, terutama industri dengan eksplorasi air tanah yang tinggi. Selain penggunaan air tanah untuk rumah tangga, penyebab lainnya adalah serapan tanah yang jauh sudah berkurang sekarang ini. Hal tersebut dikarenakan hilangnya hutan sebagai cadangan air tanah dan air hujan. Oleh karenanya sangat penting untuk mempertimbangkan faktor kesadaran akan keberlangsungan air dalam penilaian kinerja perusahaan secara keseluruhan, tidak hanya keuntungan semata.

\section{World Research Institute}

memetakan dengan jelas risko adanya kekurangan air tahun 2040 untuk setiap negara seperti terlihat pada Gambar 1.

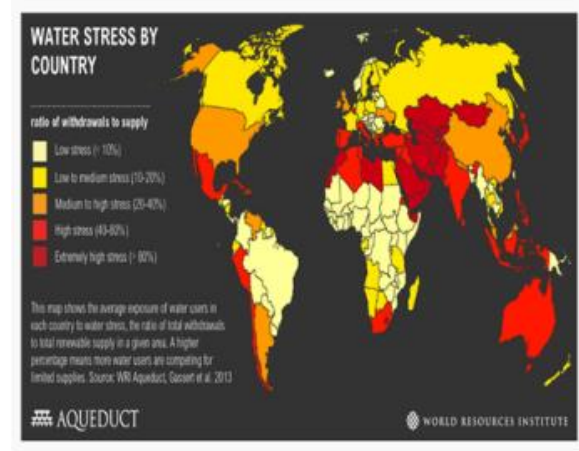

Gambar 1

Peta Water Stress Setiap Negara (WRI, 2017)
Kinerja seringkali dikaitkan dengan kepuasan pemegang saham dan tingkat keberhasilan perusahaan. Teori stakeholder menurut John dan Senbet (1998) menyatakan bahwa secara komprehensif terdapat banyak pihak yang memiliki kepentingan dan bersaing dalam proses operasional perusahaan. Mereka menekankan peran mekanisme non-market seperti ukuran struktur dewan dan komite sebagai faktor yang cukup relevan dengan kinerja perusahaan. Dalam pasar bisnis saat ini yang kompetitif, tidak mudah untuk perusahaan dapat serta merta meningkatkan kinerja perusahaan yang dilihat dari aspek keuangan maupun non keuangan. Standar Akuntansi Keuangan IAI (2017) menyatakan bahwa kinerja keuangan merupakan kemampuan perusahaan untuk mengelola dan mengendalikan sumber daya mereka, yang dapat dilihat dari kemampuan perusahaan meningkatkan harga saham, yang pada akhirnya memberikan keuntungan maksimum bagi mereka (Nurlela dan Islanudin, 2008); (Muliani et al, 2014). Perilaku yang mencerminkan kesadaran dari nilai air dan konsekuensi ekonomi atas pasokan air di negara yang kekurangan air sangat penting dibangun dengan strategi yang tepat (Shupin dan Zahner, 1990). Terlebih bagi perusahaan manufaktur yang banyak mengeksplorasi air, pelaporan kegiatan perusahaan terkait keberlangsungan sumber air menjadi hal yang perlu dipertimbangkan untuk penilaian kinerja perusahaan.

Penelitian ini memiliki kontribusi baik secara teoritis maupun praktis. Hasil analisis yang diperoleh dapat digunakan sebagai acuan literasi selanjutnya akan pentingnya kesadaran 
akan keberlanjutan air. Sehingga seluruh entitas korporasi, terutama sektor manufaktur dapat memahami, mengimplementasikannya dan menyampaikannya dalam laporan kinerja perusahaan. Pelaporan kegiatan pencegahan tersebut kemudian dapat dipublikasikan kepada seluruh pemangku kepentingan, sebagai bentuk pertanggungjawaban manajemen.

\section{KAJIAN PUSTAKA DAN HIPOTESIS}

Analisa terhadap literatur terkait kinerja dilakukan oleh Richard et al (2009) dengan mengidentifikasi 207 variabel kinerja yang berbeda dari 213 makalah yang diterbitkan selama 2006 sampai dengan 2009. Temuannya yaitu bahwa kienrja organisasi terdiri dari output aktual dari suatu organisasi yang diukur terhadap output yang ditargetkan perusahaan yang mencakup tiga bidang tertentu yaitu profitabilitas, Return On Assets (ROA) dan Return on Equity (ROE). Namun studi baru-baru ini secara intensif melihat kinerja perusahan tidak hanya keuangan, namun juga non keuangan. Kaplan dan Norton (2004) menyatakan bahwa ukuran kinerja non keuangan merupakan indikator yang lebih baik dari kinerja keuangan di masa yang akan datang.

Indikator non keuangan juga diharapkan dapat dijadikan sebagai rujukan terhadap dampak yang akan dialami perusahaan di masa yang akan datang atas keputusan perusahaan yang telah diambil. Fernandes et al (2006) melakukan pengukuran terhadap kinerja non keuangan dalam cakupan yang lebih luas. Kotane dan Merlino (2012) menyatakan bahwa hasil non- keuangan positif mempengaruhi hasil kegiatan keuangan dan meningkatnya jumlah manajer perusahaan kemudian mengubah sistem evaluasi kinerja perusahaan mereka, dalam rangka untuk menentukan strategi baru dalam bisnis yang kompetitif dengan melacak indikator evaluasi kinerja perusahaan non-keuangan. Meskipun sebagian besar peneliti belum menyepakati isi dan struktur dari indikator non-keuangan dan metode pengukuran dan evaluasi yang paling tepat untuk digunakan. Di sisi lain, Jawad (2012) mengulas tentang kesadaran masalah air di Yordania, menemukan bahwa kesadaran masyarakat akan situasi dan kondisi air masih rendah dan kemudian merekomendasikan pelaksanaan program yang tepat dilakukan guna meningkatkan kesadaran air.

Rerangka pemikiran dibuat untuk mempermudah pemahaman keterkaitan antara kesadaran akan keberlangsungan air (Water Awareness) terhadap kinerja perusahaan dari aspek non keuangan. Peneliti menyajikan rerangka pemikiran dalam Gambar 2 berikut:

Kesadaran Air (Water Awareness):

1)Kepercayaan Pasokan Air;

2)Pengetahuan Kualitas Air;

3)Kualitas Air yang Didapatkan;

4)Pengetahuan akan Pencemaran Air.

5)Kesadaran akan Keberlanjutan Air

H1

Kinerja Perusahaan

(Non Keuangan)

\section{Gambar 2}

Kerangka Pemikiran 
Kesadaran Air Terhadap Kinerja Perusahaan

Kesadaran perusahaan akan kualitas air sangat penting untuk memastikan keberlangsungan sumber air. Studi di Yordania menemukan bahwa mayoritas responden tidak mempercayai kualitas air terjaga dengan baik (Jawad, 2012). Ketidakpercayaan perusahaan akan pasokan air, akan mendorong perusahaan untuk mengantisipasi keberlangsungan sumber air dengan baik. Tindakan pencegahan dilakukan sebagai bentuk akan adanya kekhawatiran akan habisnya sumber air. Harapan akan adanya pasokan air yang cukup, maka akan memungkinan perusahaan terus beroperasi dengan baik, oleh karenanya peneliti mengajukan hipotesis berikut:

\section{$\mathrm{H1}_{\mathrm{a}}$ : Kepercayaan perusahaan terhadap pasokan air akan meningkatkan kinerja perusahaan.}

Jawad (2012) juga menemukan bahwa pada negara berkembang seperti Yordania, sebagian besar masyarakatnya masih belum memahami benar tentang kualitas air. Sebagian besar responden tidak mendapatkan informasi mengenai pemahaman akan kualitas air dengan benar. Pengetahuan yang baik akan kualitas air yang dimiliki oleh sumber daya manusia dalam suatu perusahaan, dapat mendorong implementasi pencegahan pencemaran air. Hal ini tentu akan meningkatkan kinerja perusahaan di kemudian hari. Sehingga peneliti mengajukan hipotesis sebagai berikut:

\section{$\mathrm{H1}_{\mathrm{b}}$ : Pengetahuan akan kualitas air dapat meningkatkan kinerja perusahaan.}

Produk manufaktur yang sebagian besar bahan bakunya berasal dari air, akan sangat mementingkan kualitas air. Kualitas air yang didapatkan dalam proses pengolahan tersebut menentukan kualitas produk. Dengan kualitas air yang baik, maka akan diiringi oleh kualitas produk yang terjaga dan terjamin. Oleh karenanya, kepastian akan kualitas air bersih yang didapatkan oleh perusahaan memiliki peran penting dalam upaya menjaga dan meningkatkan kinerja perusahaan manufaktur. Sehingga peneliti mengajukan hipotesis berikut:

\section{H1: Kepastian akan kualitas air yang didapatkan dapat meningkatkan kinerja perusahaan.}

Manajemen perusahaan perlu memastikan memiliki sumberdaya dengan pemahaman pengetahuan tentang air yang cukup. Mengetahui bagaimana pengolahan air limbah yang benar, dan dampak yang timbul atas kesalahan pengolahan air limbah tersebut. Karena sebagian besar sumberdaya pada negara berkembang tidak memiliki pengetahuan yang cukup tentang penyebab tercemarnya sumber air bersih (Jawad, 2012). Antisipasi perusahaan untuk menempatkan sumberdaya yang memiliki pengetahuan akan penyebab pencemaran air, dapat membantu manajemen untuk memastikan keberlangsungan air bersih. Sehingga operasional perusahaan terus berjalan, dengan kinerja yang baik pula. Oleh karenanya peneliti mengajukan hipotesis berikut:

\section{$H 1_{d}$ : Pengetahuan akan pencemaran air dapat meningkatkan kinerja perusahaan.}

Kesadaran akan keberlanjutan sumber air menjadi kunci keberlangsungan operasional perusahaan. Eksplorasi air yang berlebihan menyebabkan sumber air akan semakin terbatas. Air seringkali 
dianggap sebagai "barang bebas". Padahal semakin terbatas jumlahnya, maka hukum ekonomi tidak akan terhindarkan. Semakin terbatas, maka akan semakin mahal, karna air merupakan salah satu benda ekonomis (Hartono, 2014). Perusahaan manufaktur selayaknya memiliki sumber daya manusia yang sadar akan keberlanjutan air. Hal ini untuk memastikan upaya menjaga ketersediaan air bagi produksinya. Tanpa adanya air yang cukup, maka menyebabkan tidak adanya kepastian akan keberlangsungan usaha. Sehingga peneliti mengajukan hipotesis berikut:

\section{H1 $1_{\mathrm{e}}$ : Kesadaran keberlanjutan air dapat meningkatkan kinerja perusahaan.}

\section{METODE PENELITIAN}

Populasi dalam penelitian ini adalah perusahaan yang terdaftar di Bursa Efek Indonesia pada tahun 2017 yang menerbitkan Laporan Keuangan. Purposive sampling digunakan untuk mendapatkan sampel. Yaitu dipilih perusahaan manufaktur yang diduga mengeksplorasi air dalam jumlah banyak. Selain itu, peneliti berfokus pada letak area operasional perusahaan yang berada di daerah perkotaan. Setiap perusahaan dalam sampel diwakili oleh lima (5) dari responden. 1 (satu) responden dari tingkat manajerial, 2 (dua) responden dari tingkat tengah (supervisor) dan 2 (dua) responden merupakan staf junior. Kriteria pemilihan responden adalah karyawan dari posisi yang sesuai di perusahaan jangka minimal masa kerja satu (1) tahun. Penelitian ini menggunakan metode regresi linier yang diolah dengan SPSS 25.
Variabel independen berupa kesadaran air (Water Awareness) mengacu pada indikator milik Jawad (2012), lebih spesifik dalam hal upaya menjaga kualitas air bagi keberlangsungan usaha. Indikator tersebut yaitu :1).Kepercayaan adanya pasokan air (KP); 2).Pengetahuan Kualitas Air (PK); 3.)Kualitas Air yang Didapatkan (KA); 4).Pengetahuan akan Pencemaran Air (PP) dan 5). Kesadaran akan Keberlanjutan Air (KK). Indikator tersebut dianggap sesuai karena mencerminkan upaya manajemen untuk memperhatikan kualitas air dan menghindari kesalahan pengelolaan limbah air. Limbah air yang tidak ditangani dengan baik justru akan merusak kualitas air bersih, sehingga mengancam keberlangsungan operasional usaha.

Sedangkan variabel dependen yang digunakan dalam penelitian ini adalah kinerja non keuangan perusahaan. Indikator kinerja nonkeuangan diharapkan menjadi rujukan bagi upaya penanggulangan dampak dari tindakan yang diambil oleh manajemen, termasuk dalam pengelolaan air. Fernandes et al (2006) untuk mengukur kinerja non-keuangan untuk perusahaan manufaktur dalam tiga dimensi yaitu : 1). Pelanggan / Customer terkait; 2). Internal Proses / Internal Bisnis dan 3). Upaya Belajar dan Bertumbuh / Inovasi / Belajar.

Pengukuran ini kemudian digunakan oleh Kotane (2012) untuk mengevaluasi kegiatan bisnis perusahaan. Seluruh variabel tersebut diukur dengan menggunakan skala linkert lima point, yaitu sangat tidak setuju (STS), tidak setuju (TS), netral (N), setuju (S), dan sangat setuju (SS). 
Skala Linkert (Linkert Scale) merupakan skala penelitian yang biasa digunakna untuk mengukur sikap dan pendapat responden. Responden diharapkan untuk dapat menjawab pertanyaan, dimana di dalamnya mengharuskan mereka menunjukkan tingkat persetujuan terhadap serangkaian pertanyaan. Oleh karenanya, peneliti harus secara spesifik harus menggunakan pernyataan ataupun pertanyaan yang mengarah pada dimensi yang diukur. Nama Skala ini diambil dari nama penciptanya yaitu Rensis Likert, seorang ahli psikologi sosial dari Amerika Serikat.

\section{HASIL DAN PEMBAHASAN}

\section{Gambaran Umum Objek Penelitian}

Secara umum dapat dilihat bahwa populasi penelitian ini adalah perusahaan manufaktur yang terdaftar pada Bursa Efek Indonesia (BEI) pada tahun 2017. Sedangkan sampel penelitian merupakan perusahaan manufaktur yang memenuhi kriteria dengan diwakili oleh 5 responden untuk masing-masing perusahaan. Pengambilan data kuisioner dapat terlihat dalam Tabel 3.

\section{Tabel 3}

\section{Gambaran Umum Objek Penelitian (Sampel)}

\begin{tabular}{|c|c|c|c|c|}
\hline & & $\mathrm{N}=101$ & Jumlah & Persentase \\
\hline \multirow[t]{2}{*}{ Jenis Kelamin } & Laki-Laki & & 71 & $70.3 \%$ \\
\hline & Perempuan & & 30 & $29.7 \%$ \\
\hline \multirow[t]{4}{*}{ Usia } & $25-34$ & & 16 & $15.8 \%$ \\
\hline & $35-44$ & & 55 & $54.5 \%$ \\
\hline & $45-54$ & & 20 & $19.8 \%$ \\
\hline & $>=55$ & & 10 & $9.9 \%$ \\
\hline \multirow[t]{3}{*}{ Pengalaman Kerja } & $>10$ Tahun & & 36 & $35.6 \%$ \\
\hline & 6-10 Tahun & & 60 & $59.4 \%$ \\
\hline & 1-5 Tahun & & 5 & $5.0 \%$ \\
\hline \multicolumn{5}{|l|}{ Tingkat } \\
\hline \multirow[t]{4}{*}{ Pendidikan } & Tersertifikasi & & 16 & $15.8 \%$ \\
\hline & Diploma & & 15 & $14.8 \%$ \\
\hline & Sarjana & & 65 & $64.3 \%$ \\
\hline & Pasca Sarjana & & 5 & $4.95 \%$ \\
\hline
\end{tabular}

Tabel 3 memberikan gambaran umum responden yang didominasi oleh laki-laki yaitu sebanyak 71 responden $(70.3 \%)$, dan responden perempuan sebanyak 30 orang (29.7\%). Sebaran usia responden didominasi oleh rentang usia 3544 tahun sebanyak 55 responden (54.5\%), disusul dengan rentang usia 45-54 tahun sebanyak 20 responden (19.8\%). Berikutnya merupakan kategori usia lebih dari 55 tahun sebanyak 10 responden $(9.9 \%)$.

Tingkat pengalaman kerja didominasi rentang waktu antara 6-10 tahun, yaitu sebanyak 60 responden (59.4\%), disusul dengan masa kerja lebih dari 10 tahun $(35.6 \%)$ dan terakhir masa kerja 1-5 tahun sebanyak 5 responden (5\%). Tingkat pendidikan didominasi Sarjana sebanyak 65 responden (64.3\%), disusul tingkatan Tersertifikasi sebanyak 16 responden (15.8\%). Selanjutnya sebanyak 15 responden (14.8\%) pada tingkat Diploma, dan terakhir 5 responden (4.95\%) tingkat Pasca Sarjana.

Dari data demografi tersebut diatas memperlihatkan bahwa mayoritas perusahaan manufaktur memiliki sumberdaya yang sesuai dengan kebutuhan perusahaan. Usia produktif, dengan pengalaman kerja yang cukup matang, dan dengan latar belakang pendidikan yang tinggi.

Kemudian hasil analisa penyebaran kuisioner dilakukan untuk mengetahui dan memastikan efiktifitas penyebaran penggunaan kuisioner dengan dimensi dan pengukuran yang telah ditentukan oleh peneliti. Hasil analisa penyebaran kuisioner tersebut telihat pada tabel dibawah ini. 
Tabel 4

Data Penyebaran Kuisioner

\begin{tabular}{|r|r|c|c|}
\hline $\mathbf{N}$ & Keterangan & Jumlah & \% \\
\hline o & & & \\
\hline 1. & Kuisioner & 135 & $100 \%$ \\
& & & \\
\hline 2. & Kuisioner & $(19)$ & $(14 \%)$ \\
& Yang Tidak & & \\
& Lengkap & & \\
\hline 3. & Kuisioner & $(14)$ & $(10 \%)$ \\
& Yang Tidak & & \\
& Konsisten & & \\
\hline & $\begin{array}{r}\text { Kuisioner } \\
\text { Yang Dapat }\end{array}$ & $\mathbf{1 0 1}$ & $\mathbf{7 6 \%}$ \\
& Diolah & & \\
\hline
\end{tabular}

Sumber: Data Primer Yang Diolah (2019)

Tabel 4 memperlihatkan bahwa terdapat 125 responden yang mengisi kuisioner. Namun hanya $76 \%$ atau 101 kuisioner yang dapat diolah. Terdapat 14\% atau 19 kuisioner yang tidak diisi dengan lengkap, dan $10 \%$ atau 14 responden yang mengisi kuisioner tidak konsisten. 101 kuisioner tersebut kemudian diolah dengan SPSS Versi 25. Penggunaan software tersebut sesuai fungsi dan kebutuhan pengolahan data yang diperlukan dalam penelitin ini.

\section{UJI ANALISIS DATA DAN UJI HIPOTESIS}

Peneliti melakukan uji validitas dan reliabilitas pada 20 orang responden. Hasil menunjukkan bahwa terdapat konsistensi dan kesesuaian pengukuran dengan hubungan antara kesadaran akan air dan kinerja perusahaan. Kemudian peneliti melakukan uji validitas pada 100 responden. Hasil uji validitas dan reliabilitas pada 100 responden menunjukkan arah yang lebih kuat. Detail hasil uji tersebut disajikan dalam Tabel 5 dan Tabel 6.
Hasil uji tersebut dengan menggabungkan data keseluruhan faktor yang diteliti untuk menunjukkan Kesadaran Akan Air (Water Awareness) dalam 5 dimensi yaitu: 1). Kepercayaan Pasokan Air; 2). Pengetahuan Kualitas Air; 3).Kualitas Air yang Didapatkan; 4).Pengetahuan akan Pencemaran Air. Serta 5) Kesadaran akan Keberlanjutan Air. Disamping itu, menampilkan juga hasil uji akan kinerja perusahaan sebagai variabel tidak bebas.

Tabel 5

Hasil Uji Validitas dengan $\mathrm{N}=\mathbf{2 0}$

Sumber: Data Primer Yang Diolah (2019)

\begin{tabular}{|c|l|c|c|c|}
\hline No. & Variable & $\mathbf{r}^{\text {count }}$ & $\mathbf{r}^{\text {table }}$ & Remark \\
\hline 1 & $\begin{array}{l}\text { Kesada- } \\
\text { ran Air }\end{array}$ & 0.514 & 0.360 & valid \\
\hline 2 & $\begin{array}{l}\text { Kinerja } \\
\text { Perusa- } \\
\text { haan }\end{array}$ & 0.553 & 0.360 & valid \\
\hline
\end{tabular}

Table 6

Hasil Uji Validitas dengan $\mathrm{N}=100$ Sumber: Data Primer Yang Diolah (2019)

\begin{tabular}{|l|l|c|c|c|}
\hline No. & Variable & $\mathrm{r}^{\text {count }}$ & $\mathrm{r}^{\text {table }}$ & Remark \\
\hline 1 & $\begin{array}{l}\text { Kesadaran } \\
\text { Air }\end{array}$ & 0.627 & 0.165 & valid \\
\hline 2 & $\begin{array}{l}\text { Kinerja } \\
\text { Perusahaan }\end{array}$ & 0.859 & 0.165 & valid \\
\hline
\end{tabular}

Kemudian uji linier dilakukan untuk memastikan hubungan kedua variabel yang diteliti. Hasil pengujian uji regresi linier atas faktor Kepercayaan Pasokan Air (KP), Pengetahuan Kualitas Air (PK), Kepastian Kualitas Air yang Didapatkan (KK), Pengetahuan akan Pencemaran Air (PP) dan Kesadaran akan Keberlanjutan Air 
(KB) terhadap Kinerja Perusahaan disajikan dalam Tabel 7 berikut.

\section{Tabel 7}

\section{Hasil Uji Regresi Linier Coefficient ${ }^{a}$}

\begin{tabular}{|r|r|r|r|r|}
\hline \multicolumn{1}{|c|}{ Model } & $\begin{array}{c}\text { Unstan- } \\
\text { dardized } \\
\text { Coeffi- } \\
\text { cients }\end{array}$ & $\begin{array}{c}\text { Standardized } \\
\text { Coefficients }\end{array}$ & \multicolumn{1}{c|}{} & Sig. \\
\hline 1. (Constant) & 2974.724 & 1.889 & 2.727 & .000 \\
$\mathrm{KP}$ & 127.322 & .368 & .239 & .001 \\
$\mathrm{PK}$ & 0.133 & .140 & -.084 & .257 \\
$\mathrm{KA}$ & 2.443 & .778 & .570 & .024 \\
$\mathrm{PP}$ & 5.316 & .881 & -1.357 & .069 \\
$\mathrm{~KB}$ & 1.012 & .266 & .223 & .016 \\
\hline
\end{tabular}

a. Dependent: Kinerja Perusahaan

Dari Tabel 7 diatas, hasil uji parsial masing-masing independen terhadap dependen terlihat jelas bahwa Kepercayaan pada Pasokan Air, Kepastian Kualitas Air dan Keberlanjutan Air dapat mendorong kinerja perusahaan, namun tidak demikian dengan Pengetahuan Kualitas Air dan Pengetahuan Pencemaran Air. Atau dapat dikatakan bahwa Hipotesis 1a (H1a), Hhipotesis 1c (H1c) dan Hipotesis 1e (H1e) diterima. Namun tidak demikian dengan Hipotesis $1 b$ (H1b) dan juga Hipotesis 1d (H1d) yang ternyata ditolak.

Hasil perhitungan secara simultan terlihat pada Tabel 8. Uji F ini bertujuan untuk mengetahui ada atau tidaknya pengaruh simultan variabel independen terhadap dependen. Dalam hal ini adalah untuk mengetahui pengaruh Kesadaran Air terhadap Kinerja Perusahaan secara Non Keuangan. Data memperlihatkan bahwa Kesadaran Air (Water Awareness) berpengaruh terhadap Kinerja
Perusahaan. Analisa ini terlihat dari hasil olah data yang memperlihatkan nilai signifikansi yang ada yaitu sebesar 0,00, atau lebih kecil dari 0,05 . Sehingga model yang diajukan oleh peneliti dapat dikatakan baik. Model yang baik dapat digunakan untuk memprediksi hasil, namun tidak demikian apabila model terbukti tidak baik atau tidak signifikan.

Tabel 8

\section{Hasil Uji F}

ANOVAa

\begin{tabular}{|c|c|c|c|c|c|c|}
\hline Model & $\begin{array}{l}\text { Sum of } \\
\text { Squares }\end{array}$ & Df & $\begin{array}{l}\text { mean } \\
\text { Square }\end{array}$ & $\mathrm{F}$ & $\begin{array}{c}\mathrm{T} \\
\text { Table }\end{array}$ & Sig. \\
\hline $11 \begin{array}{l}\text { Regression } \\
\text { residual } \\
\text { Total }\end{array}$ & $\begin{array}{l}1.435 \\
2.510 \\
3.945\end{array}$ & $\begin{array}{r}5 \\
34 \\
39 \\
\end{array}$ & $\begin{array}{r}.408 \\
.080\end{array}$ & 5.296 & 2.617 & $.000 \mathrm{~b}$ \\
\hline
\end{tabular}

b. Predictors: (Constant), Kesadaran Air

\section{KESIMPULAN}

Berdasarkan paparan hasil analisa data serta pembahasan variabel atas potensi kenaikan Kinerja Perusahaan, maka dapat disimpulkan bahwa jika faktor kepercayaan atas ketersediaan air, kepastian akan kualitas air dan kesadaran akan keberlanjutan air meningkat maka dapat meningkatkan kinerja perusahaan. Namun faktor pengetahuan akan kualitas air dan faktor pengetahuan akan pencemaran air tidak berpengaruh. Dapat disimpulkan bahwa secara umum perusahaan akan lebih memperhatikan ada tidaknya cadangan air serta kepastian kualitas air dengan alat, dibandingkan upaya meningkatkan pengetahuan yang cukup untuk menjaga keberlanjutan air. Pengetahuan akan kualiatas air, ataupun pengetahuan mengenai adanya pengetahuan lebih lanjut akan pentingnya faktor yang dapat mencemari kualitas air tersebut. Meskipun secara keseluruhan perusahaan dalam 
sample telah memahami bahwa keberlangsungan air turut berperan dalam keberlanjutan kinerja perusahaan.

Penelitian ini memiliki beberapa kelemahan, yaitu faktor yang diteliti masih sebatas kesadaran perusahaan tentang keberlangsungan air. Diperlukan studi lebih lanjut yang mempelajari mengenai bagaiamana perusahaan mengatur suplai air atau Water Supply Sistem Management. Hasil penelitian ini juga tidak dapat digeneralisir pada jenis industri lain, karena penelitian ini hanya berfokus pada manufaktur. Penelitian kedepan dapat menggunakan sample lebih luas dan membandingkan dengan berbagai negara berkembang lainnya, sehingga hasil dapat dibandingkan.

\section{UCAPAN TERIMA KASIH}

Penelitian ini memperoleh hibah internal dari Lembaga Penelitian dan Pengabdian Kepada Masyarakat Universitas Pembangunan Jaya dengan nomor kontrak 006/PER-P2M/ UPJ.05.19. Mendapat dukungan dari sivitas Program Studi Akuntansi serta mahasiswamahasiswi Universitas Pembangunan Jaya dalam penyebaran dan pengumpulan data. Atas dukungan dan bantuan tersebut, peneliti mengucapkan terima kasih.

\section{DAFTAR PUSTAKA}

ACCA. (2010). Disclosures on water. Accountants for Business

Baiocchi, V: Lelo, K and Vatore, F.(2015). Boolean Logic Model for an Environmental Protection Plan on A Local Administration Terriotry. Geographia Technica, Vol 10, Issue No. 2/2015, pp 1-
Boutera, M: Roubhia, A; Lakheneche, D and Xeereg, S. (2012). Wastewater Rejection Iimpact on Groundwater Wuality in A Semi Arid Region. Case of Tebessa Aquifer, Geography Technica, No. 1/2012, pp.19-27

Brigham, Eugen F. and Joel F. Houston. (2009). Fundamentals of Financial Management. Jakarta: Four Salemba

Freeman, R.E. (2004). A Stakeholder Theory of Modern Corporations, Ethical Theory and Business, 7 th edn

Gilley, R., Sullivan, R., Tang, S. \& Tarbet, A., (2006). Water Conservation in Windhoek Schools, City of Windhoek: The Department of Infrastructure, Water and Technical Services

Globe Telecom. (2019). ASEAN Corporate Governance Scorecard. Available at https:// www.globe.com.ph/about-us/corporategovernance/asean-corporate-governancescorecard.html

Gujarati, D. (2003). Basic Econometrics. Jakarta: Erland

Hartono, D., M. (2014). Sistem Air Minum dan Permasalahannya. Conference: Seminar Co Creation World Water Day 2014 At: Depok, Indonesia.

Jawad, A.D. (2012). Water issues and Accounting Awareness. American Journal of Scientific Research ISSN 1450-223X Issue 60 (2012), pp. 46-53 C EuroJournals Publishing, Inc. 2012http:// www.eurojournals.com/ajsr.html.

Jensen, Michael C. and William H. Meckling. (1976). Theory of the Firm: Managerial Behavior, Agency Costs, and Ownership 
Structure. Journal of Financial Economics, Vol. 3, pp. 305-360

Johnson, G. (2009). Measuring Organizational Performance: Towards Best Practice methodological. Journal of Management, Vol.35 No.3, pp.718-804

Kotane, I and Merlino.(2012).Non Financial Indicator for Evaluation of Business Activity. Riga International School of Economics and Business Administration. DOI 10.5755 / j01.ei

OECD.2017. The OECD Equity Markets Review of Asia. (2017). OECD Asian Roundtable on Corporate Governance, Tokyo. Available online at https:// www.oecd.org/daf/ca/2017-oecd-asianroundtable-on-corporate-governance.html Richard, PJ; Devinney, TM;Yip, GS and Turner, G; Baynes, TM; McInnis, B.C (2010). A Water Accounting System for Strategic Water Management.Water Resources Management Journal. DOI:10/1007/s11269009-9457-7

Water Supply Regulatory Agency of Jakarta. (2018). Jakarta Drinking Water Crisis. Available online athttp://www.brpamdki.org Wiersma, E. (2008). An exploratory study of the relative and incremental information content of two non-financial performance measures: Field study evidence of absence on frequency and on-time delivery. Accounting, Organizations and Society, Vol.33, P.249-265. 